\title{
Integrasi Pendekatan Metode Custom Hashing dan Data Partitioning untuk Mempercepat Proses Pencarian Frekuensi Item-set pada Algoritma Apriori
}

Moch. Syahrir, Fatimatuzzahra

Universitas Bumigora, Indonesia

\section{Article info}

Article history:

Received, 8 August 2020

Revised, 5 September 2020

Accepted, 15 September 2020

\section{Kata kunci:}

Apriori

Aturan Asosiasi

FP-Growth

Hashing

Data Partisi

Keywords:
Apriori
Association Rule
FP-Growth
Hashing
Data Partitioning

Keywords:

Association Rule

Data Partitioning

\begin{abstract}
ABSTRAK
Data mining dengan peran asosiasi sudah banyak digunakan oleh dunia usaha, salah satu algoritma yang sering digunakan untuk aturan asosiasi adalah apriori. Namun apriori memiliki kelemahan dalam hal performa, karena pada setiap penentuan frequent $k$-itemset harus melakukan scan database. Hal ini akan menjadi masalah apabila kandidat $k$-itemset memiliki dimensi yang banyak. proses scan database yang besar akan memakan waktu yang lama dan berpengaruh pada penggunaan memori dan prosesor. Apriori sudah sering dikembangkan, salah satu yang populer adalah Frequent Pattern (fp-growth), apriori dan $f p$-growth sama-sama merupakan algoritma untuk aturan asosiasi, hanya saja $f p$-growth menggunakan pendekatan yang berbeda dengan apriori yakni menggunakan pendekatan Frequent Pattern Tree ( $f p$-tree). Meski $f p$ growth memiiki performa yang bagus ketika scan database namun rules yang di hasilkan oleh fp-growth tidak sebaik yang di hasilkan oleh apriori. Alternatif lain yang bisa digunakan adalah metode hashing, hal ini bisa menjadi solusi untuk mengatasi masalah dalam proses pencarian dan penentuan frequent $k$ itemset, sehingga proses scan database bisa lebih cepat. Tujuan penelitian adalah memperbaiki kinerja apriori dalam proses pencarian frekuensi itemset sehingga waktu scan database bisa lebih cepat
\end{abstract}

\section{ABSTRACT}

Data mining with the role of association has been widely used by the business world. One of the algorithms often used for association rules is a priori. However, a priori has a weakness in terms of performance, because every frequent $k$-itemset determination has to scan the database. This will be a problem if the $k$-itemset candidate has many dimensions. scanning large databases will take a long time and will affect memory and processor usage. Apriori has often been developed, one of the popular ones is that fp-growth, a priori and fp-growth are both algorithms for association rules, it's just that fpgrowth uses a different approach from a priori, namely using the fp-tree approach. Even though fp-growth has good performance when scanning the database, the rules generated by fp-growth are not as good as those generated by a priori. Another alternative that can be used is the hashing method, this can be a solution to solving problems in the search process and determining frequent $k$-itemset, so that the database scan process can be faster. The research objective was to improve a priori performance in the itemet frequency search process so that the database scan time could be faster

This is an open access article under the CC BY-SAlicense.

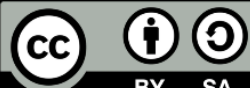

Penulis Korespondensi:

Moch. Syahrir,

Program Studi Ilmu Komputer,

Universitas Bumigora.

Email: muhammadsyahriralfath@gmail.com 


\section{PENDAHULUAN}

Algoritma untuk association rules sangat banyak diantaranya apriori, eclat, fp-growth, mafia dan lainlain. Akan tetapi algoritma yang paling umum di kembangkan sebagai dasar pengembangan dan baseline method adalah apriori [1], sebagaimana yang telah di utarakan oleh para peneliti bahwa masalah yang paling umum pada apriori adalah scan database secara berulang-ulang untuk mendapatkan frekuensi itemset dengan kombinasi-kombinasi item tertentu, sehingga akan banyak memakan waktu dan memori komputer yang sangat besar untuk scan database [2]. Seiring berjalannya waktu dan berkembangnya teknologi mulai bermunculan algoritma-algoritma hasil pengembangan dari apriori tersebut dan yang paling populer adalah fp-growth dengan pendekatan $f p$-tree. Dengan konsep $f p$-tree, item-item sebagai fitur di bentuk dalam sebuah kerangka pohon dengan lintasan-lintasan tertentu yang sangat padat [3], sehingga scan database hanya dilakukan satu atau dua kali. Menurut para ahli dan peneliti fp-growth bukan tanpa masalah, permasalahan yang terdapat pada fp-growth adalah rules yang dihasilkan oleh fp-growth tidak sebaik rules yang dihasilkan oleh apriori [2]. Dan juga cara implementasi fp-growth tidak semudah cara mengimplementasikan apriori walaupun ini hal yang relative []].

Fp-growth dikembangkan dari algoritma apriori, tentu keduanya saling melengkapi, Fp-growth dalam proses pencarian frekuensi itemset sudah sangat baik dari algoritma apriori namun rules yang dihasilkan tidak sebaik algoritma apriori. Permasalahan yang muncul adalah bagaimana bisa mempertahankan rules optimal yang di hasilkan oleh algoritma apriori dan mengurangi waktus scan database berulang-ulang. Salah satu alternatif dengan memanfaatkan tabel hashing yang di bentuk dengan menggunakan metode hashing dengan key, dihasilkan dari sebuah perhitungan fungsi yang bervariasi. Kita bisa menentukan key dalam tabel hashing lalu memanggil key tersebut untuk melakukan pencarian dan penghapusan data [ㅁ] pemanfaatan metode hasing untuk menyimpan alamat key dalam menentukan frekuensi itemset.

Metode hashing adalah teknik untuk melakukan penambahan data, penghapusan, dan pencaraian data dengan teknik menelusuri alamat key yang didapat dari sebuah aturan fungsi [5]. Fungsi hashing cukup banyak, kita tidak perlu menggunakan semua fungsi tersebut, disesuaikan dengan objek penelitian sebagai salah satu yang bisa di gunakan adalah Modular Aritmatic yakni melakukan konversi data ke bilangan bulat lalu di bagi dengan ukuran tabel hash dan mengambil hasil sisa bagi sebagai indeks atau key [్]. Sebuah fungsi hashing yang bagus memiliki dua kriteria yakni harus cepat dapat dihitung dan harus meminimalkan terjadinya collision. Dalam beberapa jurnal penelitian fungsi hashing sudah banyak di modifikasi, tujuannya tidak lain yakni meminimalkan terjadinya collisiondan mudah dapat di hitung.

Data mining adalah disiplin ilmu yang mempelajari metode untuk mengekstrak pengetahuan atau menemukan pola dari suatu data yang besar [7]. Tahap-tahap data mining:

1. Seleksi Data

Data tidak semuanya dipakai, oleh karena itu hanya data yang sesuai untuk dianalisis yang akan diambil dari database.

2. Preprosesing Data

Data yang sudah di pilih di lakukan pembersihan data, dan integrasi data untuk menggabungkan beberapa data ke dalam database baru.

\section{Transformasi Data}

Data diubah dan digabungkan ke dalam format yang sesuai untuk proses dalam data mining. Transformasi dapat di lakukan dengan cara sebagai berikut:

1. Smooting untuk menghilangkan noise dari data

2. Attribute Construction, dimana attribut baru di buat atau ditambahkan untuk membantu proses mining

3. Aggreation, dimana ringkasan atau operasi agrerasi diterapkan pada data.

4. Normalization, dimana data attribut dibuat dalam skala tertentu sehingga menjadi kisaran data yang lebih kecil dan sebaran datanya tidak terlalu jauh.

5. Proses Mining merupakan suatu proses utama saat metode diterapkan untuk menemukan pengetahuan berharga dan tersembunyi dari data. Terdapat berbagai macam teknik dalam data mining, dimana pemilihannya bergantung pada tujuan dan proses pencarian pengetahuannya.

6. Evaluasi Pola (Pattern Evaluation) Untuk mengidentifikasi pola-pola menarik ke dalam knowledge based yang ditemukan. Kemudian dilakukan visualisasi dan penyajian pengetahuan mengenai metode yang digunakan untuk memperoleh pengetahuan yang berguna bagi pengguna. 
Algoritma apriori adalah salah satu algoritma association rules dengan teknik pengambilan data menggunakan pendekatan aturan asosiatif untuk menentukan hubungan asosiasi suatu kombinasi itemset. Penting tidaknya suatu aturan asosiatif dapat diketahui dengan dua parameter yaitu support dan confidence [7]. Support (nilai penunjang) adalah persentase kombinasi item tersebut dalam database. Confidence (nilai kepastian) adalah kuatnya hubungan antar-item dalam aturan asosiasi. Sebuah aturan asosiasi dikatakan interesting jika nilai support adalah lebih besar dari minimum support dan juga nilai confidence adalah lebih besar dari minimum confidence. Sementara untuk menguji nilai kevalidan hubungan antar item menggunakan lift rasio. Adapun formula yang digunakan untuk meghitung nilai support, confidence, dan lift rasio pada persamaan (1), (2), dan (3).

1. Formula Support:

$$
\operatorname{Support}(A, B)=\frac{\text { Jumlah Transaksi A Dan B }}{\sum \text { Transaksi }} \times 100 \%
$$

2. Formula Confidence:

$$
\text { Confidence }(A, B)=\frac{\text { Jumlah Transaksi A Dan B }}{\sum \text { Transaksi } A} \times 100 \%
$$

3. Formula Lift Rasio:

$$
\text { Lift rasio }=\frac{\text { Support }(A, B)}{\text { Support } A x \text { Support } B}
$$

Algoritma Fp-growth adalah salah satu algoritma dari teknik association rules yang dapat digunakan untuk menentukan himpunan data yang paling sering muncul (frequent itemset) dalam sebuah kumpulan data dengan pendekatan pada konsep fp-tree []].

1. Dataset

$$
\text { Cara kerja Fp-Tree: }
$$

Tabel 1. Kontruksi Fp-Tree Dari Transaksi Database

\begin{tabular}{lll} 
TID & \multicolumn{1}{c}{ Item Bougth } & \multicolumn{1}{c}{ Frequent Items } \\
100 & $\{\mathrm{f}, \mathrm{a}, \mathrm{c}, \mathrm{d}, \mathrm{g}, \mathrm{i}, \mathrm{m}, \mathrm{p}\}$ & $\{\mathrm{f}, \mathrm{c}, \mathrm{a}, \mathrm{m}, \mathrm{p}\}$ \\
200 & $\{\mathrm{a}, \mathrm{b}, \mathrm{c}, \mathrm{f}, \mathrm{i}, \mathrm{m}, \mathrm{o}\}$ & $\{\mathrm{f}, \mathrm{c}, \mathrm{a}, \mathrm{b}, \mathrm{m}\}$ \\
300 & $\{\mathrm{~b}, \mathrm{f}, \mathrm{h}, \mathrm{j}, \mathrm{o}, \mathrm{w}\}$ & $\{\mathrm{f}, \mathrm{b}\}$ \\
400 & $\{\mathrm{~b}, \mathrm{c}, \mathrm{k}, \mathrm{s}, \mathrm{p}\}$ & $\{\mathrm{c}, \mathrm{b}, \mathrm{p}\}$ \\
500 & $\{\mathrm{a}, \mathrm{f}, \mathrm{c}, \mathrm{e}, \mathrm{l}, \mathrm{p}, \mathrm{m}, \mathrm{n}\}$ & $\{\mathrm{f}, \mathrm{c}, \mathrm{a}, \mathrm{m}, \mathrm{p}\}$
\end{tabular}

2. Menentukan minimum support

Minimum support $=3$

3. Scan database untuk mendapatkan frekuensi 1 itemset

4. Pengurutan nilai frekuensi dari nilai paling tinggi sampai nilai yang paling rendah

5. Scan database lagi untuk membentuk fp-tree

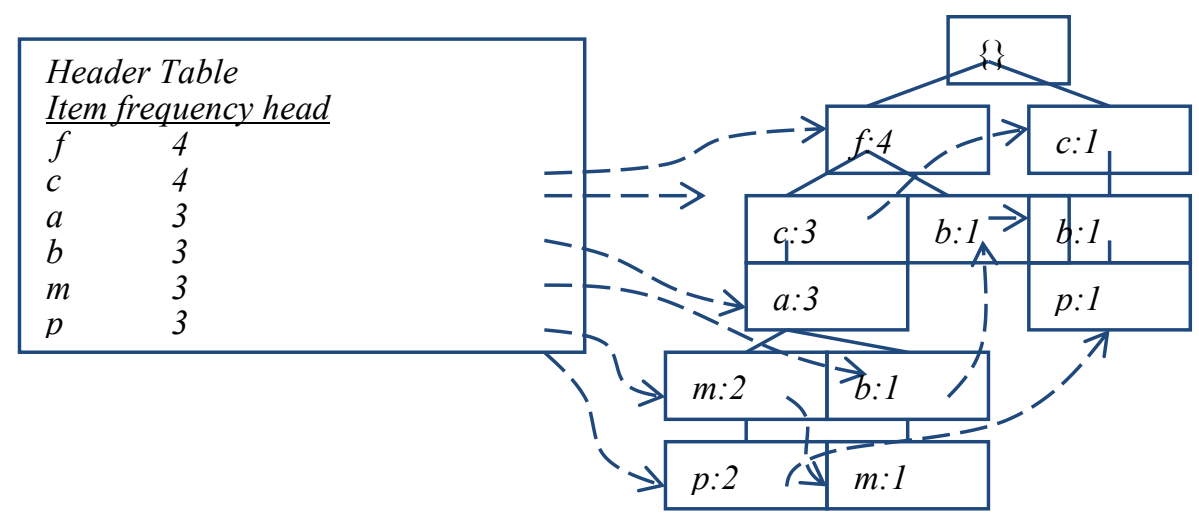

Gambar 1. Pembentukan Fp-Tree

Metode hashing adalah salah satu metode yang bisa digunakan untuk membentuk tabel array dan membentuk alamat key dengan fungsi hashing [5]. 
1. Hashing digunakan untuk menyimpan data yang cukup besar pada ADT (Abstract Data Type) yang di sebut tabel Hash.

2. Ukuran tabel Hash biasanya lebih besar dari jumlah data yang akan di simpan.

3. Fungsi Hashing memetakan elemen pada indeks dari tabel Hash.

4. Hash Table adalah Array dengan sel-sel yang ukuranya telah di tentukan dan dapat berisi data atau key yang memiliki kesamaan dengan data. Namun kita bisa juga mengganti tabel array dalam bentuk tabel sementara di mysql yang memiliki record-rocord dan primary key yang sesuai dengan data tersebut sebagai acuan untuk insert, update, delete, search, dan link.

5. Untuk menambahkan data atau pencarian ditentukan key dari data tersebut dan digunakan sebuah fungsi hashing untuk menetapkan lokasi key tersebut.

6. Untuk memetakan setiap key, fungsi hashing dapat digunakan pada bilangan dalam rentang 0 hingga HashSize -1.

Fungsi hashing cukup banyak, tidak perlu menggunakan semua fungsi tersebut, serta disesuaikan dengan objek penelitian. Salah satu fungsi hasing yang bisa digunakan adalah Modular Aritmatic yaitu dengan cara melakukan konversi data ke bilangan bulat, dibagi dengan ukuran Hash Table dan mengambil hasil sisa bagi sebagai indeks / alamat key.

Sebuah fungsi hashing yang bagus memiliki dua kriteria yakni harus dapat cepat dihitung dan harus meminimalkan terjadinya collisoin. Collisoin adalah jika dua buah key atau lebih di petakan pada sel data yang sama. Ada dua strategi umum untuk meminimalisir terjadinya collision yakni Close Hashing (Opening Addres) dan Open Hashing (Chaining).

Salah satu rumus untuk pencarian fungsi hashing yang digunakan oleh peneliti-peneliti dalam menentukan alamat keysebagai pemetaan data hasil scan database [9]. Formula standar fungsi hashing ditunjukkan pada persamaan 4 .

$$
H_{i}(x)=(\operatorname{Hash}(x)+f(i)) \operatorname{Mod} H-\operatorname{Size} f(0)=0
$$

$f(i)=$ digunakan untuk mengatur strategi collision resolution.

Namun, jika di implementasikan akan terjadi beberapa collision sehingga dalam penelitian ini fungsi hashing yang digunakan sudah dimodifikasi, tujuannya untuk mempermudah perhitungan dan meminimalkan terjadinya collision. Secara rinci bisa di lihat pada persamaan (5).

Penentuan alamat key untuk itemset.

$$
H(c)=\sum_{k=2}^{n}\left(i p * 10^{(k-1)}\right)+(i c) \operatorname{Mod} 2 * m+1
$$

$\mathrm{H}(\mathrm{c})$ adalah alamat hashing, $n$ adalah jumlah iterasi, $k$ adalah iterasi ke, ip adalah item Premises, ic adalah item Conclusion, dan $m$ adalah jumlah transaksi.

Permasalahan umum yang terdapat dalam data mining adalah banyaknya atribut sehingga kita bisa mengenal seleksi fitur dan ekstraksi fitur, akan tetapi dalam asosiasi melakukan hal ini sangat beresiko sebab item-item dari database akan menjadi atribut dataset yang akan diolah dan akan dilakukan pencarian frekuensi kemunculannya dalam sebuah tabel transaksi [9], item akan mejadi atribut yang saling berkorelasi antara satu dengan yang lainnya, apabila fitur kita kurangi dan kita ekstraksi tentu rules yang dihasilkan dari proses tersebut tidak optimal [10]. Sehingga teknik yang bisa digunakan adalah membagi atribut-atribut tersebut dan dikelompokan untuk mempercepat proses scan database tanpa memangkas pembentukan rules serta tetap mempertahankan support dan confidence yang benar dan juga dalam penelitian ini item partition berguna untuk membatasi pembentukan alamat dari fungsi hash supaya tidak terjadi collison.

Untuk menentukan state of the art dari penelitian ini penulis melakukan review terhadap beberapa paper yang relevan dengan topik yang di bahas. Ada beberapa jurnal yang membahas tentang komparasi algoritma association rules dan proses peningkatan kinerja dari pada algoritma-algoritma association rule, dan juga membahas tentang algoritma apriori di gabungkan dengan metode hashing sebagai alternatif lain dalam pengembangan ataupun menncari kebaharuan algoritma apriori sehingga kinerja algoritma apriori menjadi lebih baik. Sebagai state of the art untuk mengembangkan hasil riset dan paper oleh penulis-penulis sebelumnya yang menjadi bahan pengembangan sebagai berikut: 
Performance Comparison Of Hahshing Algoritm With Apriori [11].Dalam penelitian ini, rathin dan baskaran membuat $f p$-tree dari kumpulan dataset hasil scanning tersebut di masukan ke dalam tabel hash yang sebelumnya sudah di tentukan alamatnya. Sebagai baseline method mereka menggunakan apriori tradisional.

An effective Hash-Based Algorithm For Mining Association Rule [12].Dalam penelitian ini, phils. S. Yu membentuk tabel hash lalu memasukan data hasil scandatabase ke dalam tabel hash tersebut yang sebelumnya sudah di pangkas, dan untuk meminimalisir terjadinya collisiontabel hashmerubah fungsi dengan menambahkan konstanta ke dalam fungsi hash tersebut.

Untuk menentukan state of the art dari penelitian ini penulis melakukan review terhadap beberapa paper yang relevan dengan topik yang di bahas. Ada beberapa jurnal yang membahas tentang komparasi algoritma association rules dan proses peningkatan kinerja dari pada algoritma-algoritma association rule dan juga membahas tentang algoritma apriori digabungkan dengan metode hashing sebagai alternatif lain dalam pengembangan ataupun mencari kebaharuan algoritma apriori sehingga kinerja algoritma apriori menjadi lebih baik. Sebagai state of the art untuk mengembangkan hasil riset dan paper oleh penulis-penulis sebelumnya yang menjadi bahan pengembangan sebagai berikut:

Penelitian [11] membuat $f p$-tree dari kumpulan dataset hasil scanning tersebut dimasukan ke dalam tabel hash yang sebelumnya sudah ditentukan alamatnya. Sebagai baseline method mereka menggunakan apriori tradisional. Penelitian [12] membentuk tabel hash lalu memasukan data hasil scan database ke dalam tabel hash tersebut yang sebelumnya sudah di pangkas dan untuk meminimalisir terjadinya collision tabel hash merubah fungsi dengan menambahkan konstanta ke dalam fungsi hash tersebut. Dalam penelitian [13] membentuk $f p$-tree untuk membuat lintasan korelasi antar item serta di implementasikan dalam bentuk aplikasi data mining yang bisa menampilkan hasil secara real time.

Penelitian [14] menggunakan tabel hash untuk mempermudah penyimpanan data hasil scan dan meminamalkan kolom dalam tabel hash. Penelitian [15] lebih fokus pada penentuan fungsi dengan teknik linear probing dalam menentukan alamat key pada tabel hash.

Dalam penelitian ini ada dua pengembangan yang paling mendasar yaitu mencari alternatif lain untuk algoritma apriori agar memiliki kinerja yang lebih baik dengan mempertahankan rules yang baik dari algoritma apriori dan juga memodifikasi fungsi pada metode hashing agar collision yang terjadi dapat diminimalisir.

\section{METODE PENELITIAN}

\subsection{Sumber Data}

Data yang di peroleh adalah data private yang sudah di validasi oleh instansi terkait. Dalam hal ini KOPEGTEL (Koperasi Pegawai Telkom) Kota Mataram - Nusa Tenggara Barat (NTB). Total record data lebih kurang lebih 500 record, sementara item data lebih dari 50 item, data yang di ambil adalah data proses transaksi penjualan pada KOPEGTEL Kota Mataram. Untuk memaksimalkan kinerja algoritma association rules item akan dipartisi maksimal 15 item karena kelemahan data mining adalah ketika dimensi atau item tersebut berjumlah sangat banyak maka proses scan data memakan waktu yang lama. Sebelum data digunakan data dilakukan preprosesing, model preprosesing dilakukan dengan membentuk tabel binari binominal.

\subsection{Metodologi Penelitian}

Algoritma yang digunakan dalam penelitian ini adalah algoritma apriori, algoritma apriori sendiri adalah bagian dari algoritma-algoritma association rule. Kelemahan algoritma apriori adalah pada saat scan database dalam proses pencarian frekuensi itemset akan tetapi kelebihannya mampu menghasilkan rule yang optimal. Oleh sebab itu dalam penelitian ini penulis menggunakan metode hashing untuk memperbaiki kinerja algoritma apriori dalam proses pencarian frekuensi. Metode hashing bisa digunakan untuk menentukan alamat key, dimana alamat key ini digunakan untuk menyimpan frekuensi itemset hasil scan database. Adapun tahapantahapan dalam penelitian adalah pengumpulan data serta proses preprosesing, proses asosiasi dengan algoritma apriori tradisional, proses asosiasi dengan algoritma apriori +hashing, proses asosiasi dengan algoritma $f p-$ growth dalam tools rapidminer, dan terakhir dibuatkan grafik perbandingan.

Tahap pertama yang dilakukan yaitu mengumpulkan data. Data yang diperoleh sebanyak 500 record serta lebih dari 50 item, akan tetapi maksimal item yang dipartisi adalah 15 item. Tujuannya untuk mempermudah proses-proses selanjutnya. Data yang diperoleh adalah data private dari KOPEGTEL (Koperasi Pegawai Telkom) Kota Mataram - Nusa Tenggara Barat (NTB) yang telah di validasi oleh pihak terkait. Sebelum masuk tahap kedua data dilakukan preprosesing terlebih dahulu, model preprosesing dilakukan dengan membentuk tabel binari binominal.

Tahap kedua di lakukan proses asosiasi menggunakan algoritma apriori tradisional dengan menggunakan data yang telah di preprosessing sebelumnya serta menentukan treshold frekuensi minimum support bertujuan 
sebagai prunning agar hasil scan tidak melebar tampa ada pemangkas bagi korelasi yang di anggap di bawah treshold minimum support. Serta melakukan perhitungan support dan confidence. Untuk proses yang dilakukan beberapa tahap dengan variasi record dan threshold yang berbeda-beda. Sementara proses yang dilakukan sebanyak 4 iterasi itemset.

Tahap ketiga dilakukan proses asosiasi menggunakan algoritma apriori + hashing dengan menggunakan data dan menentukan threshold yang sama dengan tahapan sebelumnya. Dengan begitu kita dengan mudah dapat membandingkan hasil support dan confidence antara kedua algoritma tersebut serta menghitung perbedaan waktu yang di butuhkan dalam hal scan database.

Tahap ke empat dilakukan proses asosiasi menggunakan algoritma fp-growth yang memanfaatkan tools rapidminner dengan data dan treshold yang sama seperti tahap-tahap sebelumnya. Sehingga kita bisa membandingkan nilai support dan confidence dengan algoritma apriori + hashisng maupun dengan algoritma fp-growth yang telah tersedia pada rapidminner.

Setelah semua data hasil asosiasi ketiga algoritma pada tahap-tahap tersebut di buatkan dalam bentuk tabel untuk mempermudah dalam membaca dan menganalisa perbedaan.

\section{HASIL DAN ANALISIS}

\subsection{Pengujian Program.}

Pengujian program di lakukan dengan acuan perbandingan waktu scan, perbedaan nilai support, confidence, dan evaluasi nilai liftrasio. dengan ukuran data yang bervariasi baik untuk record maupun fitur. Sebagai bahan pengujian menggunakan sampel data private yang sudah di validasi oleh instansi terkait. Dalam hal ini KOPEGTEL (Koperasi Pegawai Telkom) Kota Mataram - NTB.

\subsection{Pengujian Waktu Scan Database}

Dalam tahap ini di lakukan perhitungan waktu scan database antara algoritma apriori tradisional dengan algoritma apriori + hashing.

1. Pengujian untuk 2-Itemset

Pada Gambar 2 kita bisa melihat grafik perbedaan waktu yang sangat siginifikan dalam proses pencarian frekuensi itemset antara algoritma apriori tradisional dengan algoritma apriori + hashing. Semakin banyak minimum frekuensi sebagai threshold-nya maka waktu pencarian frekuensi akan semakin lama. Karena harus terus mencari sampai batas threshold yang di tetapkan. Selain itu kita bisa melihat meskipun minimum frekuensi lebih kecil itu terkadang juga membutuhkan waktu yang lama dalam pencarian frekuensi itemset, ini disebabkan oleh item yang banyak. Item dalam algoritma-algoritma association rulesi adalah atribut atau dimensi dalam istilah data mining.

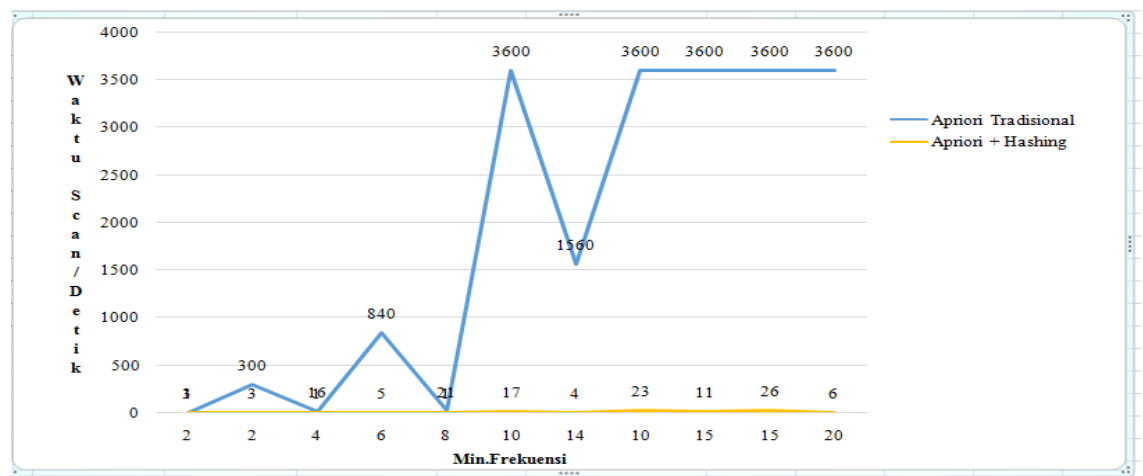

Gambar 2. Pengujian Waktu Scan 2-Itemset

2. Pengujian untuk 3-Itemset

Pada Gambar 3 kita bisa melihat perbedaan waktu scan database yang sangat signifikan sama dengan pada Gambar 2. Akan tetapi rata-rata waktu yang dibutuhkan semakin besar karena itemset bertambah. 


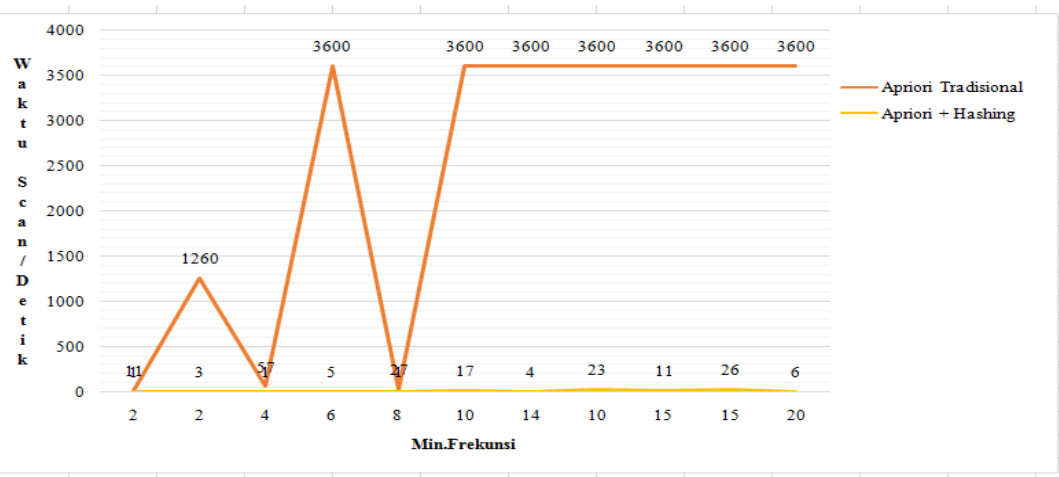

Gambar 3. Pengujian Waktu Scan 3-Itemset

\section{Pengujian Untuk 4-Itemset}

Dari Gambar 4 kita juga bisa melihat perbedaan waktu scan database yang sangat signifikan, juga karena itemset bertambah maka waktu scan database pun akan semakin lama. dengan ini kita melihat bahwa algoritma apriori yang telah di modifikasi dengan tambahan metode hashing mampu mempercepat proses pencarian frekuensi itemset dari database yang di scan.

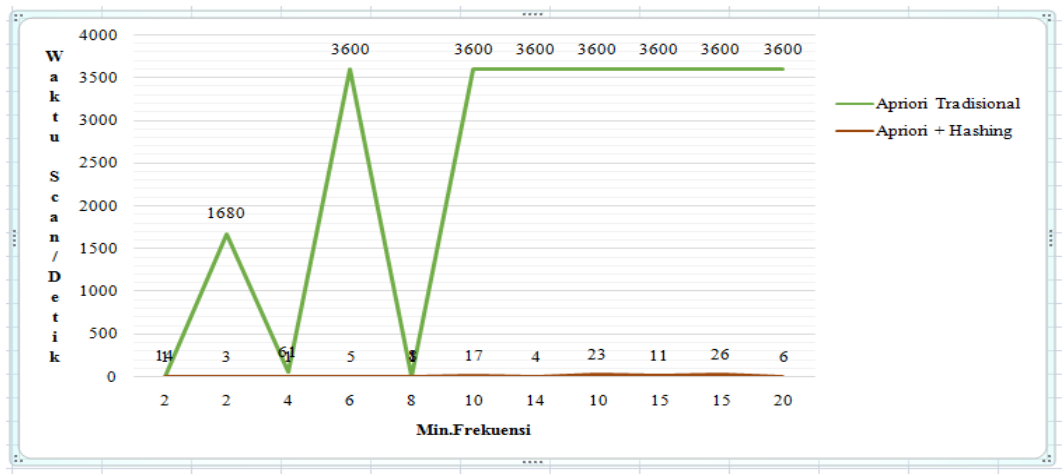

Gambar 4. Pengujian Waktu Scan 4-Itemset

Dari Gambar 4 kita bisa melihat perbedaan waktu scan database yang sangat signifikan sama dengan Gambar 2 dan Gambar 3 akan tetapi waktu yang dibutuhkan juga semakin lama dan ini berlaku untuk kedua algoritma baik apriori tradisional maupun apriori yang di modifikasi dengan metode hashing, akan tetapi tetap apriori yang telah di modifikasi yang bisa lebih cepat dalam proses scan database. Sementara hasil support dan confidence antara apriori tradisional dengan apriori + hashing tidak ada perbedaan.

\subsection{Pengujian Nilai Support Dan Confidence}

Pengujian Nilai Support Dan Confidence. Tahap pengujian ini melibatkan hasil dari ke tiga algoritma asosiasi rule yakni algoritma apriori tradisional, apriori + hashing, dan fp-growth dengan jumlah record data yang sama dan juga nilai treshold yang sama pula. Pengujian ini menggunakan threshold support minimum 0.1 dan item Premises yakni PEPSODEN.

Tabel 2. Pengujian Nilai Support Dan Confidence 2-Itemset Algoritma Apriori Tradisional dan Algoritma

\begin{tabular}{c|c|l|l|c|c|c|c}
\multicolumn{8}{c}{ Apriori + Hashing. } \\
\hline No & Tresh & Item 1 & Item 2 & \multicolumn{2}{c|}{ 2-Itemset Apriori Tradisional } & \multicolumn{2}{c}{ 2 Itemset Apriori + Hashing } \\
Supp & Conf & Supp & Conf \\
1 & 0.1 & Pepsoden & Deterjen & 64 & 0.92 & 64 & 0.92 \\
2 & 0.1 & Pepsoden & Sabun & 50 & 0.72 & 50 & 0.72 \\
3 & 0.1 & Pepsoden & Popok & 47 & 0.68 & 47 & 0.68 \\
4 & 0.1 & Pepsoden & Sampo & 42 & 0.60 & 42 & 0.60 \\
5 & 0.1 & Pepsoden & Celana & 42 & 0.60 & 42 & 0.60 \\
6 & 0.1 & Pepsoden & Gula & Supp & Conf & Supp & Conf \\
7 & 0.1 & Pepsoden & Teh & 36 & 0.52 & 36 & 0.52 \\
8 & 0.1 & Pepsoden & Kopi & 33 & 0.48 & 33 & 0.48 \\
9 & 0.1 & Pepsoden & Susu & 33 & 0.48 & 33 & 0.48 \\
10 & 0.1 & Pepsoden & Coklat & 31 & 0.44 & 31 & 0.44 \\
11 & 0.1 & Pepsoden & Gatsbi & 31 & 0.44 & 31 & 0.44 \\
12 & 0.1 & Pepsoden & Aqua & 31 & 0.44 & 31 & 0.44 \\
13 & 0.1 & Pepsoden & Roti & 28 & 0.40 & 28 & 0.40 \\
14 & 0.1 & Pepsoden & Parfum & 28 & 0.40 & 28 & 0.40 \\
\hline
\end{tabular}


Tabel 3. Pengujian Nilai Support Dan Confidence 3-Itemset Algoritma Apriori Tradisional dan Algoritma Apriori + Hashing

\begin{tabular}{|c|c|c|c|c|c|c|c|c|}
\hline No & Tresh & Item 1 & Item 2 & Item 3 & $\begin{array}{l}\text { 3-Itemset } \\
\text { Tradisional } \\
\text { Supp }\end{array}$ & $\begin{array}{l}\text { Apriori } \\
\text { Conf }\end{array}$ & $\begin{array}{l}\text { 3-Itemset } \\
\text { Hashing } \\
\text { Supp }\end{array}$ & $\begin{array}{l}\text { Apriori } \\
\text { Conf }\end{array}$ \\
\hline 1 & 0.1 & Pepsoden & Deterjen & Sabun & 44 & 0.70 & 44 & 0.70 \\
\hline 2 & 0.1 & Pepsoden & Deterjen & Popok & 44 & 0.70 & 44 & 0.70 \\
\hline 3 & 0.1 & Pepsoden & Deterjen & Celana & 42 & 0.66 & 42 & 0.66 \\
\hline 4 & 0.1 & Pepsoden & Deterjen & Sampo & 39 & 0.61 & 39 & 0.61 \\
\hline 5 & 0.1 & Pepsoden & Popok & Celana & 39 & 0.82 & 39 & 0.82 \\
\hline 6 & 0.1 & Pepsoden & Gula & Deterjen & 36 & 0.93 & 36 & 0.93 \\
\hline 7 & 0.1 & Pepsoden & Gula & Sabun & 36 & 0.93 & 36 & 0.93 \\
\hline 8 & 0.1 & Pepsoden & Sampo & Popok & 33 & 0.80 & 33 & 0.80 \\
\hline 9 & 0.1 & Pepsoden & Sabun & Pokok & 31 & 0.61 & 31 & 0.61 \\
\hline 10 & 0.1 & Pepsoden & Sabun & Kopi & 31 & 0.61 & 31 & 0.61 \\
\hline 11 & 0.1 & Pepsoden & Gula & Kopi & 31 & 0.79 & 31 & 0.79 \\
\hline 12 & 0.1 & Pepsoden & Deterjen & The & 31 & 0.48 & 31 & 0.48 \\
\hline 13 & 0.1 & Pepsoden & Deterjen & Susu & 31 & 0.48 & 31 & 0.48 \\
\hline 14 & 0.1 & Pepsoden & Deterjen & Gatsbi & 31 & 0.48 & 31 & 0.48 \\
\hline 15 & 0.1 & Pepsoden & Sabun & Aqua & 28 & 0.56 & 28 & 0.56 \\
\hline 16 & 0.1 & Pepsoden & Gula & Coklat & 28 & 0.71 & 28 & 0.71 \\
\hline 17 & 0.1 & Pepsoden & Gula & Aqua & 28 & 0.71 & 28 & 0.71 \\
\hline 18 & 0.1 & Pepsoden & Sampo & Celana & 28 & 0.67 & 28 & 0.67 \\
\hline 19 & 0.1 & Pepsoden & Deterjen & Kopi & 28 & 0.43 & 28 & 0.43 \\
\hline 20 & 0.1 & Pepsoden & Teh & Susu & 28 & 0.77 & 28 & 0.77 \\
\hline 21 & 0.1 & Pepsoden & Deterjen & Roti & 28 & 0.43 & 28 & 0.43 \\
\hline 22 & 0.1 & Pepsoden & Deterjen & Coklat & 28 & 0.43 & 28 & 0.43 \\
\hline 23 & 0.1 & Pepsoden & Deterjen & Aqua & 28 & 0.43 & 28 & 0.43 \\
\hline
\end{tabular}

Tabel 4. Pengujian Nilai Support Dan Confidence 2-Itemset Algoritma Fp-Growth Dan Algoritma Apriori + Hashing

\begin{tabular}{|c|c|c|c|c|c|c|c|}
\hline \multirow{2}{*}{ No } & \multirow{2}{*}{ Tresh } & \multirow{2}{*}{ Item 1} & \multirow{2}{*}{ Item 2} & \multicolumn{2}{|c|}{ 2-Itemset Fp-Growth Rapidminer } & \multicolumn{2}{|c|}{2 Itemset Apriori + Hashing } \\
\hline & & & & & Conf & Supp & Conf \\
\hline 1 & 0.1 & Pepsoden & Deterjen & 64 & 0.92 & 64 & \\
\hline 2 & 0.1 & Pepsoden & Sabun & 50 & 0.72 & 50 & 0.72 \\
\hline 3 & 0.1 & Pepsoden & Popok & 47 & 0.68 & 47 & 0.68 \\
\hline 4 & 0.1 & Pepsoden & Sampo & 42 & 0.60 & 42 & 0.60 \\
\hline 5 & 0.1 & Pepsoden & Celana & 42 & 0.60 & 42 & 0.60 \\
\hline 6 & 0.1 & Pepsoden & Gula & 39 & 0.56 & 39 & 0.56 \\
\hline 7 & 0.1 & Pepsoden & Teh & 36 & 0.52 & 36 & 0.52 \\
\hline 8 & 0.1 & Pepsoden & Kopi & 33 & 0.48 & 33 & 0.48 \\
\hline 9 & 0.1 & Pepsoden & Susu & 33 & 0.48 & 33 & 0.48 \\
\hline 10 & 0.1 & Pepsoden & Coklat & 31 & 0.44 & 31 & 0.44 \\
\hline 11 & 0.1 & Pepsoden & Gatsbi & 31 & 0.44 & 31 & 0.44 \\
\hline 12 & 0.1 & Pepsoden & Aqua & 31 & 0.44 & 31 & 0.44 \\
\hline 13 & 0.1 & Pepsoden & Roti & 28 & 0.40 & 28 & 0.40 \\
\hline
\end{tabular}

Pada tabel 2 dan table 3 kita bisa melihat bagaimana algoritma apriori + hashing tetap mempertahankan support, confidence dan rules yang memang di hasilkan oleh apriori tradisional yang terkenal baik akurasinya. Tetapi pada tabel 4 ada satu rule yang tidak terbentuk, nilai support dan confidence tidak masuk pada ambang treshold dan juga nilai support dan confidence yang di hasilkan oleh algoritma fp-growth dalam tools rapidminner sedikit berbeda dan lebih kecil, karena pada dasarnya algoritma yang digunakan dalam tools rapidminner tersebut adalah algoritma fp-growth dengan pendekatan fp-tree yang mana rules yang di hasilkan tidak sebaik algoritma apriori [11].

\section{KESIMPULAN}

Dari hasil yang telah di peroleh nilai support dan confidence antara algoritma apriori tradisional dengan apriori + hashing tidak ada perbedaan akan tetapi untuk mendapatkan hasil tersebut ke dua algoritma ini membutuhkan waktu yang berbeda dalam melakukan proses scan database dimana algoritma apriori + hashing jauh lebih baik dibanding algoritma apriori tradisional dengan perbedaan efisiensi waktu yang cukup jauh. Dan juga menjadi catatan penting semakin banyak fitur yang terseleksi akan semakin banyak waktu yang di perlukan untuk proses scan database.

Sementara hasil lain yang kita peroleh yakni nilai support dan confidence antara algoritma apriori + hashing dengan fp-growth terjadi perbedaan nilai walaupun pada umumnya kebanyakan yang sama. Kenapa hal ini bisa terjadi, karena konsep kerja dan pendekatan dari ke dua algoritma ini berbeda meskipun tujuannya sama yakni aturan asosiasi. Fp-growth melakukan pendekat $f p$-tree, dimana $f p$-tree membentuk lintasanlintasan yang padat sehingga hasil rules yang di hasilkan fp-growth tidak sebaik apriori. Tujuan dari penelitian 
ini yakni meningkatkan kinerja algoritma apriori dalam hal kecepatan proses scan database pada saat pencarian frekuensi itemset dengan mempertahankan hasil rules yang optimal dari algoritma apriori tradisional tercapai.

Untuk pengembangan di harapkan bisa menentukan banyak fitur yang paling ideal untuk proses scan itemset sehingga bisa lebih mengoptimalkan hasil kerja dari algoritma apriori +hashing ini. Dan juga di harapkan algoritma apriori thashing ini di kembangkan lagi dengan teknik yang berbeda yakni pendekatan algoritma eclat +query joinserta melakukan komprasi untuk kedua algoritma tersebut.

\section{UCAPAN TERIMA KASIH}

Penulis ucapkan terima kasih

\section{REFERENSI}

[1] X. Wu et al., "Top 10 Algorithms in Data Mining," Knowledge and Information Systems, vol. 14, no. 1, pp. 1-37, 2008.

[2] R. M. Chezian and K. S. Kumar, "A Survey on Association Rule Mining using Apriori Algorithm," International Journal of Computer Applications, vol. 45, no. 5, 2012.

[3] M. North, Data Mining for the Messes. Utah: CreateSpace Independent Publishing Platform, 2016.

[4] L. Jian-ping, W. Ying, and Y. Fan-ding, "Incremental Mining Alogorithm Pre-FP in Association Rules Based on FP-tree," in First International Conference on Networking and Distributed Computing, 2010, pp. 199-203.

[5] J. Pieprzyk and B. Sadeghiyan, Design of Hashing Algorithms. Berlin: Springer Berlin Heidelberg, 2006.

[6] V. Kashyp and A. K. Gupta, "A Review on Modern Approach: New Parameter for Recent Improvement of Apriori Algorithm," International Journal of Computer Science and Mobile Computing, vol. 4, no. 12, 2015.

[7] C. C. Aggarwal, Data Mining: The Textbook. Switzerland: Springer, 2015.

[8] J. Han and M. Kamber, Data Mining: Concepts and Techniques, 2nd ed. San Fransisco: Elsevier Science \& Technology, 2006.

[9] D. T. Larose, Data Mining Method and Model. Canada: Wiley, 2007.

[10] V. Kotu and B. Deshpande, Predictive Analytics and Data Mining: Concepts and Practice with RapidMiner. Burlington: Morgan Kaufmann, 2014.

[11] R. Rathinasabapathy and R. Bhaskaran, "Performance Comparison of Hashing Algorithm with Apriori," in International Conference on Advances in Computing, Control, and Telecommunication Technologies, 2009, pp. 729-733.

[12] J. S. Park, M.-S. Chen, and P. S. Yu, "An effective hash-based algorithm for mining association rules," ACM SIGMOD Record, vol. 24, no. 2, pp. 175-186, May 1995.

[13] A. Bhandari, A. Gupta, and D. Das, "Improvised Apriori Algorithm Using Frequent Pattern Tree for Real Time Applications in Data Mining," Procedia Computer Science, vol. 46, pp. 644-651, 2015.

[14] B. M. Rao and S. Aguru, "A Hash Based Frequent Itemset Mining using Rehashing," International Journal on Recent and Innovation Trends in Computing and Communication, vol. 2, no. 12, 2014.

[15] A. M. J. M. Z. Rahman, P. Balasubramanie, and P. V. Krihsna, "A Hash based Mining Algorithm for Maximal Frequent Item Sets using Linear Probing," Journal of Computer Science, vol. 8, no. 1, pp. 14-19, 2009. 
